\title{
GMR
}

\section{Soybean genotype analysis for cyst nematode resistance}

\author{
B.C.M. Juliatti ${ }^{1}$, I.F. Beloti ${ }^{2}$, L.C. Pena ${ }^{3}$ and F.C. Juliatti ${ }^{2}$ \\ ${ }^{1}$ Programa de Pós-Graduação em Fitopatologia, \\ Universidade Federal de Lavras, Lavras, MG, Brasil \\ ${ }^{2}$ Instituto de Ciências Agrárias, \\ Universidade Federal de Uberlândia, Uberlândia, MG, Brasil \\ ${ }^{3}$ Departamento de Genética, \\ Universidade Federal do Paraná, Curitiba, PR, Brasil \\ Corresponding author: B.C.M. Juliatti \\ E-mail: brenojuliatti@hotmail.com
}

Genet. Mol. Res. 16 (3): gmr16039705

Received April 19, 2017

Accepted June 20, 2017

Published July 28, 2017

DOI http://dx.doi.org/10.4238/gmr16039705

Copyright $(2017$ The Authors. This is an open-access article distributed under the terms of the Creative Commons Attribution ShareAlike (CC BY-SA) 4.0 License.

\begin{abstract}
Some species of soybean cultivars have the characteristic of resistance or alteration in survival skills, and perpetuation of nematodes (female index - FI), whose process is activated when the nematode parasitism starts and the development of new resistant cultivars is primordial to the preservation of plant productivity. The objective of this study was to identify the reaction of 101 soybean genotypes and two standards, one susceptible (M-SOY 8866) and the other resistant (BRSGO Raissa) of the Germplasm Laboratory of Federal University of Uberlândia (LAGER/UFU) improvement program, after inoculation of Heterodera glycines race 3 eggs. The evaluations 35 days after inoculation consisted of the fresh and dry weight of roots, root volume, the number of females (NF), and females index (FI). Genotypes 46 (F5: 6 BRSGO Caiapônia x 100 IAC) and 11 (Engopa 316 RR - Sel. 4) performed moderate resistance; the genotype 61 (F5: 6 Caiapônia $\mathrm{x}$ Potenza) had moderate susceptibility; and the rest of the genotypes presented susceptible. Between the genotypes, NF ranged from 9.5 to
\end{abstract}

Genetics and Molecular Research 16 (3): gmr16039705 
159.7 and FI ranged from 17 to 214.8. The coefficient of genotypic determination $\left(\mathrm{H}^{2}\right)$ was 70.28 (high) for $\mathrm{NF}$, indicating genetic variation in the genotypes tested. Estimates of genotypic $\left(r_{g}\right)$, phenotypic $\left(r_{f}\right)$, and environmental $\left(\mathrm{r}_{\mathrm{a}}\right)$ correlation coefficients had lower magnitude values $(<0.70)$. Analysis of the simple Pearson correlation was significant and positive between the variables dry weight $(\mathrm{g})$ and root volume $\left(\mathrm{cm}^{3}\right)$ but was not related to the resistance to the cyst nematode in the assay.

Key words: Number of females, Female index, Genetic resistance; Heterodera glycines; Glycine max

\section{INTRODUCTION}

Soybean in Brazil is one of the major items of agricultural production; our country ranks second in the world rankings' production of this crop, and Mato Grosso is the largest producer among states, with 29\% (USDA, 2015). According to Juliatti et al. (2005), among the main factors limiting the efficiency, profitability, and success of soybean production are diseases during the crop cycle. Worldwide, soybean has over 100 diseases (Sinclair and Backman, 1989), of which about 50 is identified inside Brazilian borders. With the increase and expansion of the productive areas of a single crop, the prevalence of the disease increases the risk of considerable economic impacts annually, along with the fluctuating weather conditions. Estimated annual losses of diseases by production will be $15-20 \%$; however, some diseases may cause losses close to 100\% (Juliatti et al., 2005; Embrapa, 2007). Globally, among the 50 genera of soybean nematodes, those most harmful, are Meloidogyne javanica (Treub) Chitwood, Meloidogyne incognita (Kofoid and White) Chitwood, Heterodera glycines (Ichinohe), Pratylenchus brachyurus (Godfrey) Filipjev and Sch., and Rotylenchulus reniformis (Linford and Oliveira) (Ferraz, 2001). Dias et al. (2009) discussed the importance of these species for the country, considering the endemic presence in several producing regions ( $M$. javanica and $M$. incognita), the high genetic variability ( $H$. glycines), and the potential risk of harm from the increased cultivated area with susceptible species ( $P$. brachyurus and $R$. reniformis). The soybean cyst nematode - SCN (H. glycines) was detected for the first time in Brazilian savanna samples (Cerrado region) in 1991/1992 (Lordello et al., 1992). According to Embrapa (2007), it is present in 10 States (MG, MT, MS, GO, SP, PR, RS, BA, TO and MA), and the area affected exceeds two million hectares. Between $30-75 \%$ yield losses commonly happens in areas infested by this nematode, which can sometimes lead to total loss of the crop production (Agrios, 1988). During the season 1999/2000, the nematode soybean cyst was responsible for an estimated damage of US\$133.2 million (Yorinori, 2000). In fact, chemical control has proven to be uneconomical, because of the high cost of nematicides, its low efficiency and the low value of soybean culture (Riggs and Wrather, 1992). The use of resistant cultivars is an essential measure to control the soybean cyst nematode. The resistance mechanism presented by the soybean cultivars is a "hypersensitivity reaction" in which the affected tissues die and the nematode cannot complete its development (Schmitt and Noel, 1984). Based on a preliminary setting up conducted in areas infested with SCN to assess the resistance of plants, Mendes and Machado (1992) stated that the main soybean cultivars recommended for Brazil at the time were susceptible. Therefore, the most widely used breeding strategy programs for resistance to $\mathrm{SCN}$ has been the incorporation selection of

Genetics and Molecular Research 16 (3): gmr16039705 
genotypes from populations originated from crosses between resistant genotypes and adapted US cultivars. As resistant cultivars were available in the country, they began to replace, with advantages, the sources of American origin (Dias et al., 2009). The objective of this study was to evaluate soybean genotypes of a germplasm source program developed by the Mycology Laboratory and Plant Protection at the Federal University of Uberlândia (LAMIP/UFU) - and the Germplasm Laboratory (LAGER/UFU) searching resistance response to the infection of the soybean cyst nematode.

\section{MATERIAL AND METHODS}

\section{Experimental information}

The study was conducted between September and October of 2014, in a greenhouse inside the Institute of Agricultural Sciences on Campus Umuarama - UFU, geographic coordinates $18^{\circ} 53^{\prime} 4.967^{\prime \prime} \mathrm{S}$ and $48^{\circ} 15^{\prime} 36^{\prime \prime} \mathrm{W}$. The experimental design adopted consisted in randomized blocks (DBC) containing five blocks distributed on a workbench. Each genotype/ variety was tagged with plastic platelets and sown in a different $450-\mathrm{cm}^{3}$ cup with a substrate containing soil and sand $(1: 2 ; \mathrm{v} / \mathrm{v})$.

\section{Genotypes evaluated}

The genetic material consisted of 101 promising genotypes, which showed desirable traits in strength tests to Asian rust (Phakopsora pachyrhizi) in the LAGER/UFU improvement program, located at Gloria Farm, and two more varieties considered resistance patterns and susceptible to SCN, BRSGO Raissa and MSOY-8866, respectively. Of the 101 promising genotypes, the parental variety IAC100 was the base for several crossings to obtain some of the genotypes, introduced by American researchers in the United States to serve a paternal and source of resistance to complex chewing insects and soybean sucking (Mcpherson et al., 2007). The seeds of the generation F5:6 were taken from pods of the respective genotypes, during the season 2013/2014, in an experimental field at the farm of Glory-UFU, and made a characterization for each lineage, depending on soybean rust resistance response in addition to the classification according to their degree of relative maturity (early maturity, groups 6 and 7).

\section{Obtaining the inoculum and inoculation}

Samples were obtained from a collection of infested soil for multiplication of SCN race 3 cysts. An aliquot of $300 \mathrm{~cm}^{3}$ of this soil was placed in a 2-L container of water, and the clods were dismantled. The suspension poured, after homogenization, passed the superposed 20- and 100-mesh sieves. With the aid of jets of water, the residue collected on the 100mesh sieve was passed to a $50-\mathrm{mL}$ glass Becker. The suspension was poured into a funnel containing folded filter paper in a conical shape. After passing the whole liquid, the filter paper was removed from the funnel and opened for removal of viable cysts. These, in turn, were separated and placed on a 200-mesh sieve to be crushed, where water jets were applied to the eggs released from cysts to gain the 500-mesh sieve, which was superimposed on another 200-mesh sieve. After crushing, the residue from the 500-mesh sieve was collected to a 50-mL glass Becker. The egg suspension was calibrated with the aid of Peter-counting chamber for

Genetics and Molecular Research 16 (3): gmr16039705 
400 eggs $/ \mathrm{mL}$ and inoculation took place 7 days after seedling emergence. Three holes of $2 \mathrm{~cm}$ in depth were opened, spaced $2 \mathrm{~cm}$ from the seedling stem, and distributed in $10 \mathrm{~mL}$ of the calibrated inoculum suspension, with the aid of a pipette, constituting the initial population of 4000 eggs per cup.

\section{Sample processing and data collection}

The evaluation of the samples occurred 35 days after inoculation and consisted by the separation of the root system from the soil and weighing the roots to obtain fresh weight (FWR). Following this procedure, the roots passed in running water, so the female outside the root would fall on a 20 -mesh screen, which was superimposed on a 100-mesh sieve. The residue was then collected with the aid of jets of water from a wash bottle for a plastic cup and identified. To ensure that no loss of females to the soil at the time of separation of the roots and to verify that the first females formed would have died and become cysts, an aliquot of 150 $\mathrm{cm}^{3}$ of the soil of each cup was processed just as the root sample. Then, with the aid of a plate of plastic under a stereoscopic microscope (20X) the number of females (NF) were estimated; the total number was obtained by summing NFsoil + NFroot $=$ NFtotal genotype (Andrade et al., 1995). The behavior of the genotypes was evaluated based on the female index (FI) and calculated using the formula proposed by Anand et al. (1988).

$$
\mathrm{FI}(\%)=\frac{\text { Average of females in the genotype }}{\text { Average of females in the cultivar MSOY }-8866} \mathrm{X} 100
$$

The cultivar MSOY-8866 showed in Brazilian fields a susceptibility to the infection by race 3 of the cyst nematode, so it was used as a susceptible standard in this test. For FI $<10 \%$ the genotype was considered resistant (R); 10 to $25 \%$, moderately resistant (MR); 26 to $50 \%$, moderately susceptible (MS), and above $50 \%$, susceptible (S). The variables FWR and root dry weight (DWR) were carried out on a precision scale with up to four decimal places, and root volume (VR) was determined by placing the roots in a graduated cylinder containing a known volume of water. The difference was obtained by the direct response of the VR in equivalent units $\left(1 \mathrm{~mL}=1 \mathrm{~cm}^{3}\right)$, according to the methodology described by Basso et al. (2001).

\section{Statistical and genetic analyses}

The data were subjected to statistical analysis procedures of the SISVAR program (Ferreira, 2011) and then there was the homogeneity of variance and normality of errors through Assistat (Silva and Azevedo, 2002). Means were compared by the Scott-Knott test at $5 \%$ probability. For the genetic, phenotypic, and environmental correlations, the statistical program Genes (Cruz, 2001), simple correlations of Pearson (Sopher et al., 1917) between the variables, and the coefficient of determination that quantifies the magnitude of genetic variance (fixed effect) in this population were used.

\section{RESULTS}

The average results are statistically significant $(\mathrm{P}<0.05$, Scott-Knott test). Table 1 shows the average results of the NF, FI, VR, FWR, and DWR, for the evaluation performed after 35 days after inoculation.

Genetics and Molecular Research 16 (3): gmr16039705 
Table 1. Resistance reaction based on the number of females (NF), female index (FI), root volume (VR, $\left.\mathrm{cm}^{3}\right)$, root fresh weight (FWR, g), and root gry weight (DWR, g) of the cyst nematode (Heterodera glycines), in soybean genotypes of the breeding program LAGER/UFU.

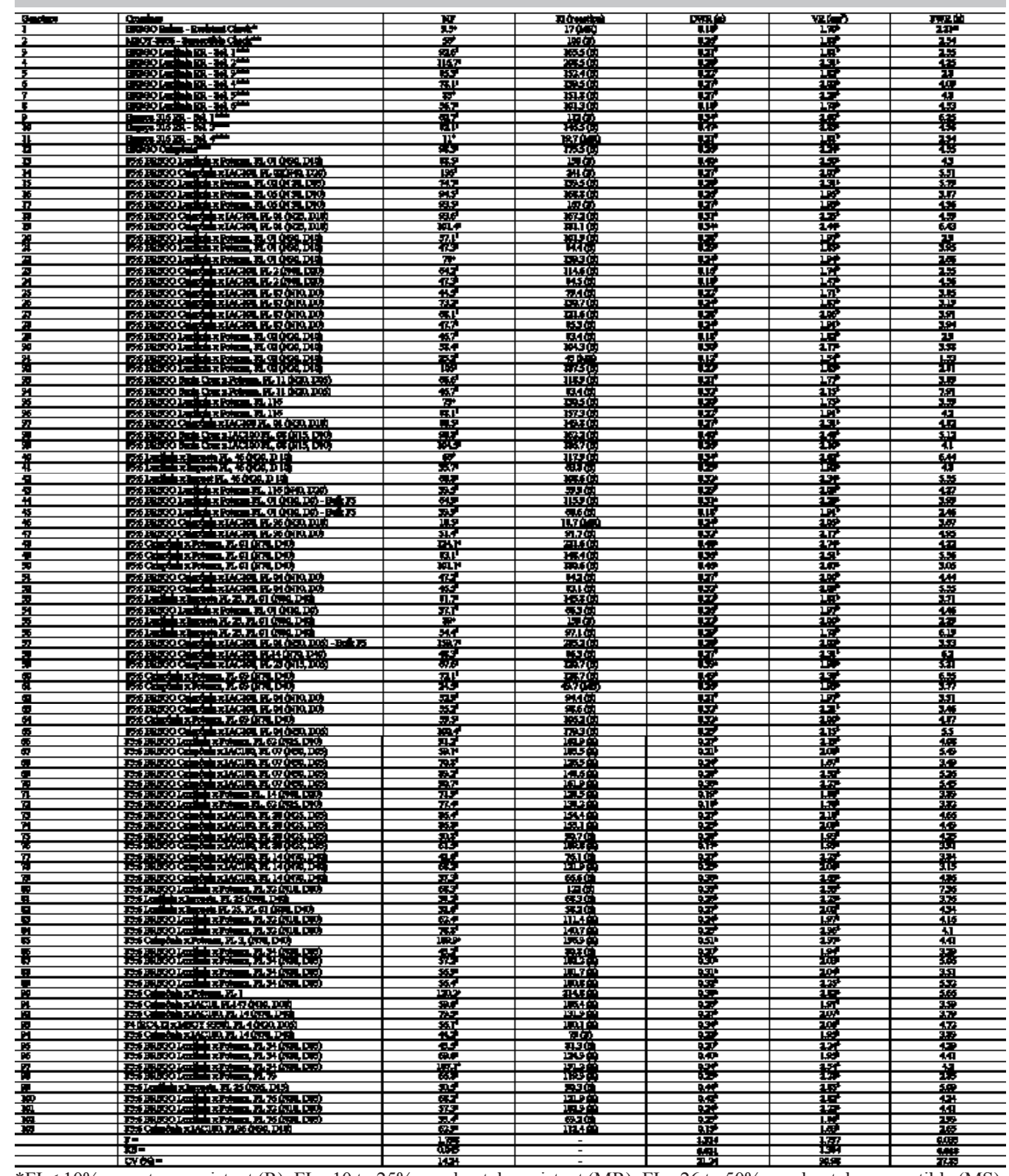

*FI $<10 \%$, genotype resistant (R); $\mathrm{FI}=10$ to $25 \%$, moderately resistant (MR); $\mathrm{FI}=26$ to $50 \%$, moderately susceptible (MS); $\mathrm{FI}=51-100 \%$, susceptible (S); FI above $100 \%$, highly sensitive (HS). ${ }^{* *} \mathrm{~ns}=$ values not significant different in the ScottKnott test at $5 \%(\mathrm{P}<0.05)$. ***Original medium. Averages, but the values were changed, for fresh weight $(\sqrt{ } \mathrm{x})$, dry weight $(\sqrt{ } \mathrm{x})$, and root volume $[\log (\mathrm{x}+1)]$, respectively. Means followed by the same letter in the column do not differ by the ScottKnott test at 5\% probability. Values of $\mathrm{F}$ and KS in bold mean homogeneous variance and waste for normal distribution by the Levene test and Kolmogorov-Smirnov, respectively; bothat a significance level of 0.05 .

Genetics and Molecular Research 16 (3): gmr16039705 
There were significant differences among genotypes $(\mathrm{P}<0.05)$, whereas the number of females got different values (Table 1). Regarding the FI, there is the formation of three heterogeneous groups of genotypes, a susceptible group (S), moderately susceptible (MS), and moderately resistant (MR) to the cyst nematode. In this experiment, two genotypes, according to female index, had moderate resistance to race 3 of $H$. glycines: genotype 46 (Crossing F5:6 BRSGO Caiapônia x IAC100) and 11 (Engopa 316 RR - Sel. 4). Other two had moderate susceptibility: genotype 61 (F5:6 Caiapônia x Potenza) and 31 (F5:6 BRSGO Luziania x Potenza, PL 02 (N20, D10), and others presented themselves as susceptible because they had a great multiplication of the nematode. It is noted that none of the resistant genotypes in response to cyst nematode showed a better average in VR assessment $\left(\mathrm{cm}^{3}\right)$, FWR $(\mathrm{g})$, and DWR (g) - the FWR did not accuse significative effect of means $(\mathrm{P}>0.05)$.

In the analysis of genetic, phenotypic, and environmental variance for the genotypes using the NF, VR, FWR, and DWR, the determination coefficients were obtained $\left(\mathrm{H}^{2}\right)$ (Table 2). These estimates showed that the differences observed in each character (variable) were predominantly of genetic nature: a high value of $70.28\left(\mathrm{H}^{2}>0.7\right)$ for genotypic determination coefficient as in the case of NF indicates the existence of a large genetic variation for the character studied. The coefficients of the other variables were 17.12 for FWR, 45.07 for VR, and 50.69 for DWR, which determined the low influence of genetic variation attributed to the variables studied (not significant, $\mathrm{H}^{2}<0$ ).

Table 2. Genotypic determination coefficient $\left(\mathrm{H}^{2}\right)$ of different characters evaluated in soybean genotypes artificially inoculated with Heterodera glycines.

\begin{tabular}{l|c}
\hline Characters & $\mathrm{H}^{2}$ \\
\hline Number of females (NF) & 70.28 \\
\hline Root fresh weight (FWR) & 17.12 \\
\hline Root dry weight (DWR) & 50.69 \\
\hline Root volume (VR) & 45.07 \\
\hline
\end{tabular}

In Table 3, the estimates of phenotypic correlation coefficients $\left(r_{f}\right)$ that obtained significant values $(\mathrm{P}<0.05$ or $\mathrm{P}<0.01)$ had low magnitude $(<0.70)$. There was no correlation between NF x FWR, NF x VR, NF x DWR, and FWR X VR, but between FWR x DWR and VR x DWR the genotypic correlation coefficient ( $\mathrm{rg}$ ) was higher than the phenotypic correlation. Regarding the analysis of the simple Pearson correlation, in the variables analyzed (Table 4) there was a positive and significant association between the variables or characters DWR and VR.

Table 3. Phenotypic $\left(r_{\mathrm{f}}\right)$, genotype $\left(\mathrm{r}_{\mathrm{g}}\right)$, and environmental $\left(\mathrm{r}_{\mathrm{a}}\right)$ correlations of four characters or variables (number of females - NF, root fresh weight - FWR, root dry weight - DWR, and root volume - VR) obtained for 103 genotypes.

\begin{tabular}{l|c|c|cc}
\hline Characters & $\mathrm{r}_{\mathrm{f}}$ & $\mathrm{r}_{\mathrm{g}}$ & \multicolumn{1}{c}{$\mathrm{r}_{\mathrm{a}}$} \\
\hline NF $\times$ FWR & $0.16^{\text {ns }}$ & 0.45 & 0.01 \\
\hline NF $\times$ VR & $0.23^{*}$ & 0.52 & 0.06 \\
\hline NF x DWR & $0.36^{* *}$ & 0.56 & 0.06 \\
\hline FWR x VR & $0.15^{\text {ns }}$ & 0.00 & 0.06 \\
\hline FWR x DWR & $0.52^{* *}$ & 0.85 & 0.41 \\
\hline VR x DWR & $0.48^{* *}$ & 0.74 & 0.38 \\
\hline
\end{tabular}

**, Significant at 1 and $5 \%$ probability by the $t$-test, respectively. ${ }^{\text {ns }}$ Not significant. 
Table 4. Pearson correlation coefficients between the variables under study.

\begin{tabular}{l|c}
\hline Characters & $\rho$ \\
\hline NF x FWR & $0.1272^{\text {ns }}$ \\
\hline NF $x$ VR & $0.339^{* *}$ \\
\hline NF $x$ DWR & $0.355^{* *}$ \\
\hline FWR x VR & $0.476^{* *}$ \\
\hline FWR x DWR & $0.4781^{* *}$ \\
\hline VR x DWR & $0.7523^{* *}$ \\
\hline
\end{tabular}

**, Significant at 1 and $5 \%$ probability by the $t$-test, respectively. ${ }^{\text {ns }}$ Not significant. For abbreviations, see Table 2.

\section{DISCUSSION}

Starting from a soil sample with a high population of the cyst nematode, Silva et al. (1999) determined an average of 223.2 in FI in the cultivar Lee 68; 175.4 in Coker 6804; and 195.6 in Hartz 6385. This result supports the appearance of a high FI in susceptible genotypes in the experiment, as presented by the genotype 57 (F5:6 BRSGO Caiapônia x IAC100, PL 01 (N50, D05) Bulk F5 obtained with high FI (285.2) as well as other susceptible genotypes, indicating the genetic segregation in obtaining the initial population in the F2 generation. Genotype 46 also obtained partial resistance to soybean rust (Phakopsora pachyrhizi) on field, in generation F4:5, where it was evaluated the partial resistance of soybean genotypes to the fungus; among the genotypes, significant differences appeared in number of average pustules and severity at 12 days after inoculation (Martins and Juliatti, 2012). The variety Engopa 316 RR - Sel. 4 (genotype 11) showed resistance or tolerance in the field, with an infestation of the cyst nematode under natural inoculation (contaminated area) and confirmed resistance in the inoculation in the greenhouse $(\mathrm{NF}=11$ and $\mathrm{FI}=19.7)$. This material possesses a susceptible characteristic to nematode race 1 infection and may be inferred to a mixture of possible seeds for the multiplication of the genotypes that possibly not derived from an inbred line. Concerning genotype 46 (F5 lineage: 6 BRSGO Caiapônia x IAC100, PL 36 (N30, D10), probably its resistance was original from parental IAC100, which features in its genealogy crossing of American cultivars BRAGG x PI 229358 (Rosseto, 1989; Veiga et al., 1999). IAC100 was created with selections made in the generation F3:4 and besides having good productivity, shows the early maturity of 111 days on average. It is important to note that the IAC100 genotype has resistance to sucking insects (Jones and Sullivan, 1979; Gilman et al., 1982). The authors reported that some plant introductions that led to this genotype showed bite resistance in insect feeding. It was subsequently confirmed resistance of IAC100 in naturally occurring infestations of soybean bug complex (Piozodorus guildinii, Euschistus spp, and Nezara viridula (Rosseto, 1989; Carro-Panizzi and Kitamura, 1995). This cultivar has two American introductions PI 229358 and PI 274454 in its genealogy (Carro-Panizzi and Kitamura, 1995), which have proven resistance to complex gift bedbugs in South America (Panizzi et al., 2000) and southern United States (Mcpherson and Mcpherson, 2000). Possibly, we can infer that the background of genotype IAC100 exists in some alleles for resistance to the cyst nematode, which during the selection in LAGER/UFU breeding program and with the advancement of its generations, allowed the expression of its gene effect for resistance in some selected strains. This hypothesis should be studied further to understand the quantitative genetic relationships, genes that are related to this source of strength and how are passed among later generations. The explanation of the low number of parental genotypes with IAC100 resistant to the cyst nematode, is by the nature of $\mathrm{SCN}$ resistance inheritance (quantitative and

Genetics and Molecular Research 16 (3): gmr16039705 
complex), involving three to four major genes and several minor genes (Dias et al., 1998). Parental genotypes that gave rise to this study mostly behaved as susceptible to SCN. It should be noted that the LAGER/UFU soybean breeding program initially focused on the Asian rust resistance and this feature was sought in parental developed strains (generation F5:6), so we performed the screening and initial study to resistance responses to pathogens of interest to soybean. Yamashita et al. (1999) evaluated soybean genotypes for resistance to Meloidogyne javanica and found that the genotype Sel. Stewart obtained reproduction factor (FR) 48.5 and FWR of $18.14 \mathrm{~g}$, while the Kitamusume genotype had FR of 47.8 and FWR of $5.23 \mathrm{~g}$; this shows that the root weight ratio and FR is an inherent genotype, whereas their reaction is specific to the studied nematode. The experimental data can infer a negative relationship between genetic resistance to cyst nematode and development and root growth.

Matsuo et al. (2012) obtained similar results on the genotypic coefficient of determination 93.63 in the NF in comparison with the value of 70.28obtained in this research. They describe in their theoretical framework that the coefficients below 0.7 or $70 \%$ cannot influence the heritability of resistance characters in the experiment, in which the variations may originate from both the genetic factor and the environmental. Values considered of low magnitude are open to various interpretations to explain the results, indicating greater reliability and possibility of success in the simplest methods of improvement, seeking to gain in selection (Nascimento Filho et al., 1994; Aragão et al., 2001; Matsuo et al., 2012). The coefficients of the other variables - 17.12 (FWR), 50.69 (DWR), and 45.07 (VR) - were considered of low magnitude, when seeking to use such characters to continue the genetic selection.

The fact that there was a correlation between NF x FWR, NF x VR, NF x DWR, and FWR X VR, highlights the strong genetic relationship between the two factors in the two correlations studied, but without application for selection-looking resistance to $H$. glycines. As these characters were not correlated with the NF, which is the primary variable or character to evaluate in the genetic resistance to $\mathrm{SCN}$, it is advised that they should not be used as a parameter for future selection. According to Cruz et al. (2004) and Matsuo et al. (2012), in pairs of variables whose genetic correlation coefficient is favorable, you can get one of them to gain by indirect selection on the other, due to the pleiotropic effects of genes. The variables or characters DWR and VR had an association in the simple Pearson correlation, but reinforcing earlier results and resuming its low importance to gains, in the genetic selection process by resistance to the cyst nematode.

We can conclude that there are genes of interest in the Brazilian germplasm, cultivar IAC100 to be continued in the study for resistance to the cyst nematode. Genotype 46 [F5:6 BRSGO Caiapônia x IAC100, PL 36 (N30, D10)], coming from the breeding program of the Germplasm of UFU Laboratory (LAGER/UFU), has moderate resistance to cyst nematode

race 3 . The NF and the IF are strong variables to characterize the genetic resistance to SCN with $\mathrm{H}^{2}$ (coefficient of genotypic determination) value of 70.28.

\section{Conflicts of interest}

The authors declare no conflict of interest.

\section{ACKNOWLEDGMENTS}

Research supported by Coordenação de Aperfeiçoamento de Pessoal de Nível Superior

Genetics and Molecular Research 16 (3): gmr16039705 
(CAPES), Syngenta, Universidade Federal de Uberlândia, Universidade Federal de Lavras, and Universidade Federal do Paraná.

\section{REFERENCES}

Agrios GN (1988). Plant Pathol. Academic Press, San Diego.

Anand SC, Gallo KM, Baker IA and Hartwig EE (1988). Soybean plant introductions with resistance to races 4 or 5 of soybean cyst nematode. Crop Sci. 37: 563-564 https://doi.org/10.2135/cropsci1988.0011183X002800030029x.

Andrade PJM, Asmus GL and Silva JFV (1995). Um novo sistema para deteç̧ão e contagem dos cistos de Heterodera glycines recuperados de amostras de solo. Fitopatol. Bras. 20: 358.

Aragão WM, Boaventura RF, Aragão RRB and Barros KBR (2001). Variabilidade e correlações entre caracteres morfológicos reprodutivos em cultivares de coqueiro-anão (Cocos nucifera L., var. nana). Agrotropica 13: 27-32 $10.1590 / \mathrm{s} 0006-87052008000100011$.

Basso SM, Voss M and Jacques AVA (2001). Nodulação e Fixação Biológica de Nitrogênio de Adesmia latifolia e Lotus corniculatus em vasos de Leonard. Rev. Bras. Zool. 30: 687-693 https://doi.org/10.1590/S1516-35982001000300012.

Carro-Panizzi MC and Kitamura K (1995). Isoflavone content in Brazilian soybean cultivars. Breed. Sci. 45: 295-300 10.1590/s0100-204X2009001100011.

Cruz CD (2001). Program Genes: computer application in genetic and statistics: the Windows version. Editora UFV, Viçosa.

Cruz CD, Regazzi AJ and Carneiro PCS (2004). Modelos biométricos aplicados ao melhoramento genético. Editora da UFV, Viçosa.

Dias WP, Silva JFV, Kiihl RA de S, Hiromoto DM, et al. (1998). Quebra da resistência da cv. Hartwig por população de campo do nematoide de cisto da soja (Heterodera glycines). Pesqui. Agropecu. Bras. 33: 971-973.

Dias WP, Silva JFV, Carneiro GES, Garcia A, et al. (2009). Nematoide do cisto da soja: biologia e manejo pelo uso da resistência genética. Nematol. Bras. 33: 1-16.

Embrapa (2007). Centro Nacional de Pesquisa de Soja. Tecnologia de produção de soja na região central do Brasil - 2007, Sistema de Produção, Londrina.

Ferraz LCB (2001). As meloidoginoses da soja: passado, presente e futuro. In: Relações parasito-hospedeiro nas meloidoginoses da soja (Silva JFV, eds.). Embrapa Soja, Soc. Bras. Nemato, Londrina, 15-38.

Ferreira DF (2011). Sisvar: a computer statistical analysis system. Cienc. Agrotec. 35: 1039-1042. https://doi.org/10.1590/ $\underline{\text { S1413-70542011000600001 }}$

Gilman DF, McPherson RM, Newsom LD, Herzog DC, et al. (1982). Resistance in soybeans to the southern green stink bug. Crop Sci. 22: 573-576 https://doi.org/10.2135/cropsci1982.0011183X002200030033x.

Jones WA and Sullivan MJ (1979). Soybean resistance to the southern green stink bug, Nezara viridula. J. Econ. Entomol. 72: 628-632 https://doi.org/10.1093/jee/72.4.628.

Juliatti FC, Polizel AC, Balardin RS and Vale FXR (2005). Ferrugem da soja: epidemiologia e manejo para uma doença reemergente. Rev. Anual Patol. Planta 13: 351-395.

Lordello AIL, Lordello RRA and Quaggio JA (1992). Ocorrência do nematoide do cisto da soja (Heterodera glycines) no Brasil. Rev. Agric. 67: 223-225.

Martins JAS and Juliatti FC (2012). Genetic control of partial resistance to Asian soybean rust. Acta Sci. Agron. Maringá, 36: 11-17.

Matsuo E, Sediyama T, Oliveira RDL, Cruz CD, et al. (2012). Avaliação de genótipos de soja em relação ao nematoide de cisto. Bragantia 71: 173-181 https://doi.org/10.1590/S0006-87052012005000016.

Mcpherson JE and Mcpherson RM (2000). Stink bugs of economic importance in America and north of Mexico. CRC Press, Boca Ratón.

Mcpherson RM, Buss GR and Roberts PM (2007). Assessing stink bug resistance in soybean lines containing genes from germplasm IAC100. J. Econ. Entomol. 100: 1456-1463.

Mendes ML and Machado CC (1992). Levantamento preliminar da ocorrência do nematoide de cisto da soja (Heterodera glycines Ichinohe), no Brasil. Embrapa-CNPSo, Londrina, 5.

Nascimento Filho FJ, Garcia TB and Cruz CD (1994). Estimativa de parâmetros genéticos em clones de guaranazeiro. Pesqui. Agropecu. Bras. 29: 91-96.

Panizzi AR, Parra JRP, Santos CH and Carvalho DR (2000). Rearing the southern green stink bug using an artificial dry diet and an artificial plant. Pesqui. Agropecu. Bras. 35: 1709-1715 https://doi.org/10.1590/S0100-204X2000000900002.

Riggs RD and Wrather AJ (1992). Biology and Management of the soybean cyst nematode. APS Press.

Genetics and Molecular Research 16 (3): gmr16039705 
Rosseto CJ (1989). SOJA IAC-100. Instituto Agronômico, Campinas.

Schmitt DP and Noel GR (1984). Nematodes' parasites of soybean. In: Plant and insect nematode (Nickle WR, ed.). Marcel Dekker, New York, 1: 13-59.

Silva FAZ and Azevedo CAV (2002). Versão do programa computacional Assistat para o sistema operacional Windows. Rev. Bras. Prod. 4: 71-78.

Silva JAL, Sediyama T and Cecon PR (1999). Avaliação da resistência de 22 variedades e genótipos americanas e nacionais de soja à Heterodera glycines, raça 3. Nematol. Bras. 23: 15-19.

Sinclair JB and Backman PA (1989). Compendium of soybean diseases. APS Press, Saint Paul.

Sopher HE, Young AW, Cave BM, Lee A, et al. (1917). On the distribution of the correlation coefficient in small samples - appendix II to the papers of "Student" and R. A. Fisher: a co-operative study. Biometrika 11: 328-413 $10.2307 / 2331830$.

Veiga RFA, Rossetto CJ, Razera LF, Gallo PB, et al. (1999). Caracterização Morfológica e Agronômica do Cultivar de Soja IAC 100. Inst. Agron., Campinas, 22.

USDA (2015). Overview. United States Department of Agriculture. Available at [http://www.ers.usda.gov/topics/crops/ soybeans-oil-crops.html]. Accessed January 5, 2015.

Yamashita OM, Silva JFV, Dias WP and Goulart AMC (1999). Reação de genótipos de soja tipo alimento ao nematoide do cisto de soja, Heterodera glycines e ao nematoide de galha, Meloidogyne javanica. Nematol. Bras. 23: 17-24.

Yorinori JT (2000). Controle integrado das principais doenças da soja. In: Soja (Câmara GMS, ed.). Tecnol. Prod. II. ESALQ/LPV, Piracicaba, 203-221.

Genetics and Molecular Research 16 (3): gmr16039705 